\title{
Caenorhabditis elegans unc-51 gene required for axonal elongation encodes a novel serine/threonine kinase
}

\author{
Ken-ichi Ogura, ${ }^{1}$ Chantal Wicky, ${ }^{2}$ Laurent Magnenat, ${ }^{2}$ Heinz Tobler, ${ }^{2}$ Ikue Mori, ${ }^{1}$ Fritz Müller, ${ }^{2}$ \\ and Yasumi Ohshima ${ }^{1}$ \\ ${ }^{1}$ Department of Biology, Faculty of Science, Kyushu University, Hakozaki, Higashi-ku, Fukuoka 812, Japan; ${ }^{2}$ Institute \\ of Zoology, University of Fribourg, Pérolles, CH-1700 Fribourg, Switzerland
}

\begin{abstract}
Mutations in the unc-51 gene of the nematode Caenorhabditis elegans result in various abnormalities in axonal elongation and axonal structures. We cloned the unc-51 gene by tagging with the transposon Tc1. The wild-type unc-51 gene, which rescued the mutant phenotypes, encodes a novel serine/threonine kinase of 856 amino acids. Mutation sites were identified in the unc-51 gene of six mutants. A Lys $\rightarrow$ Met mutation created in vitro in the kinase domain led to the loss of rescuing activity and was dominant negative, indicating that the kinase domain of Unc-51 is essential for the function. Expression of an unc-51/lacZ fusion gene was observed in many neurons at all stages. We propose that protein phosphorylation by the unc-51 product is important for axonal elongation and possibly for axonal guidance.
\end{abstract}

[Key Words: C. elegans; unc-51; axonal elongation; serine/threonine kinase]

Received July 5, 1994; revised version accepted August 30, 1994.

Construction of a complex neural network needs formation of axons and their guidance to the correct targets. Although many genes or proteins that are thought to be involved in this process have been identified (Dodd and Jessell 1988; Harrelson and Goodman 1988; Skene 1989; Hedgecock et al. 1990; Hall and Hedgecock 1991; McIntire et al. 1992; Li et al. 1992; Leung-Hagestaijn et al. 1992; Ishii et al. 1992; Goodman and Shatz 1993; Hamelin et al. 1993), the mechanism of axonal formation is still unclear. To analyze this mechanism, we have used the nematode Caenorhabditis elegans, because every neuron and the entire neuronal network of this animal have been identified by electron microscopy (White et al. 1986; Chalfie and White 1988) and because various molecular and genetic techniques are available.

The unc (uncoordinated movement)-51 gene of the nematode C. elegans was initially described by Brenner (1974). Although normal worms move actively on agar plates, unc-51 mutants are mostly paralyzed, egg-laying defective, and dumpy. These behavioral defects are most probably related to defects in axonal formation, which has been observed in several specific neurons as described below. The reason for the dumpy phenotype is not known.

Six pairs of amphid neurons in the head and two pairs of phasmid neurons in the tail are thought to be chemosensory neurons in C. elegans (Hedgecock et al. 1985; Bargmann and Horvitz 1991). They take up 5-fluorescein isothiocyanate (FITC) and can be stained easily without fixation of the worms (Hedgecock et al. 1985).
The two pairs of phasmid neurons (PHA, PHB) can also be stained with the monoclonal antibody TY21 (Siddiqui 1989|. In unc-51 mutants, each of the posterior processes of these neurons was normal, but their anterior processes terminated prematurely at the ventral nerve cord, and the terminals tended to be enlarged (Hedgecock et al. 1985). The PDE neurons, which are likely to be mechanosensory neurons, do not normally take up FITC; but in certain mutants such as cat- 6 or che-14 with abnormal mechanosensilla, these neurons sometimes can be stained with FITC (Hedgecock et al. 1985; Perkins et al. 1986). In unc-51 mutants, the PDE neurons extended abnormal numbers of axons in abnormal directions, and these axons frequently had large varicosities close to the cell body (Hedgecock et al. 1985).

The HSN motor neurons control vulval muscles, and abnormalities of these neurons lead to the egg-laying defective phenotype (Desai et al. 1988). By use of an antibody specific to serotonin, these neurons were observed immunocytochemically (Desai et al. 1988; McIntire et al. 1992). In unc-51 mutants, the HSN neurons entered the ventral nerve cord, but they failed to grow anteriorly along the ventral nerve cord. They also included ectopic, abnormally large varicosities near the cell body with extra neurites (Desai et al. 1988; McIntire et al. 1992).

The DD and VD neurons are thought to be inhibitory motor neurons in C. elegans (White et al. 1986; Chalfie and White 1988; McIntire et al. 1993a,b). These neurons are GABA-ergic and can be stained with antibody to GABA (McIntire et al. 1992, 1993a,b) or with the mono- 
clonal antibody to $\beta$-tubulin (Siddiqui 1989, 1990). In unc-51 mutants, the DD and VD axons are either prematurely terminated or are misdirected during circumferential elongation to the dorsal nerve cord (Siddiqui 1990; McIntire et al. 1992; see Fig. 2, below). In addition to these abnormalities, unc-51 mutants have axonal defects in ALM, AVM, PLM, PVM, PHC, and PVN neurons (Siddiqui 1988, 1989, 1990; Siddiqui and Culotti 1991).

In unc-51 mutants, axonal abnormalities have been observed in all the neurons examined to date; hence, this gene product plays an important role in construction of the neural network. In the present work, the unc-51 gene was cloned by tagging with the transposon Tc1. We demonstrate here that the unc-51 gene encodes a novel serine/threonine kinase whose activity is necessary for axonal elongation.

\section{Results}

\section{Molecular cloning of the unc-51 gene}

To clone the unc-51 gene in C. elegans, we screened progenies of a mutator strain RW7097 (Mori et al. 1988) for uncoordinated mutants. The mutator strain has a high rate of spontaneous mutation as a result of the insertion of transposons present at a high copy number, among which the Tc1 transposon is the most frequent. One isolate carried an unc mutation that was mapped to LG V. This mutation did not complement unc-51(e369) nor unc-51(e1189) mutations and reverted at a high frequency. These observations implied that this mutant had undergone insertion of a transposon in the unc-51 gene. Therefore we cloned the unc-51 gene with a Tc1 DNA probe. The DNA flanking Tc1 in the clone hybridized with a 4.3-kb EcoRI fragment in FK51 that was ob- tained by repeated backcrosses of this mutant with the wild-type N2, whereas it hybridized with a 2.7-kb EcoRI fragment in $\mathrm{N} 2$ and four revertant strains isolated from the original unc mutant (data not shown). Because the size of $T c 1$ is $1.6 \mathrm{~kb}$, the results suggest that these EcoRI fragments contain a part of the unc-51 gene.

\section{The cloned DNA rescued the unc-51 mutant phenotypes}

The 2.7-kb EcoRI fragment was physically mapped by A. Coulson (Coulson et al. 1986) on a cosmid F43A2. Initially, this cosmid was contained in a small isolated contig and was not localized precisely on the $C$. elegans genome map. It was mapped on chromosome $\mathrm{V}$ with in situ hybridization by D. Albertson (pers. comm.). Introduction of the DNA of cosmid F43A2 into the germ line rescued the uncoordinated, egg-laying defective, and dumpy phenotypes of unc-51(e369) to the wild type. A 13-kb EcoRI-SalI fragment of the cosmid (Fig. 1, subcloned in plasmid Bluescript, named $\mathrm{pF} 14$ ) also rescued completely. A 10-kb ClaI-SalI fragment within the above fragment that contains the complete coding region for the Unc-51 protein rescued, but only partially. Neither the left half (ClaI-ApaI) nor the right half (ApaISalI) of the $10-\mathrm{kb}$ fragment rescued at all.

We then asked whether the defects of unc-51(e369) mutant in the axonal elongation could also be rescued by introduction of the 13-kb DNA fragment. When the DD and VD neurons of animals rescued to non-Unc phenotype were stained with anti-GABA antibodies (McIntire et al. 1992, 1993a,b), the axonal morphology was indistinguishable from that of the wild type (Fig. 2C). On the basis of the results of transposon tagging and rescue ex-
Figure 1. Genomic organization of unc-51 gene and the results of phenotypic rescue experiments. The top line represents the $13-\mathrm{kb}$ insert of pF14 that rescues the unc-51 mutant phenotype. The exons in the unc-51 gene are boxed: Solid boxes denote the kinase domain of the unc-51 gene; stippled boxes denote the remaining translated region. SLl is the splice-leader sequence (Huang et al. 1989); ATG denotes the putative initiation codon; and STOP shows the termination codon. [Poly $(A)]$ stands for the poly $(\mathrm{A})$ addition site. The mutation sites of ks49', e369, ks38::Tc1, e432, e389, and $e 1120$ are indicated. Lines below represent the inserts of plasmids used for the rescue of unc-51(e369) by germ-line transformation. $(+)$ Complete rescue; $(+/-)$ incomplete rescue; $(-)$ no rescue. An asterisk $\left({ }^{*}\right)$ indicates a $\mathrm{K} \rightarrow \mathrm{M}$ mutation created in vitro. Abbreviations for the restriction sites: (C) ClaI; (E) EcoRI; (P) PstI; (S) SpeI; and (A) ApaI.

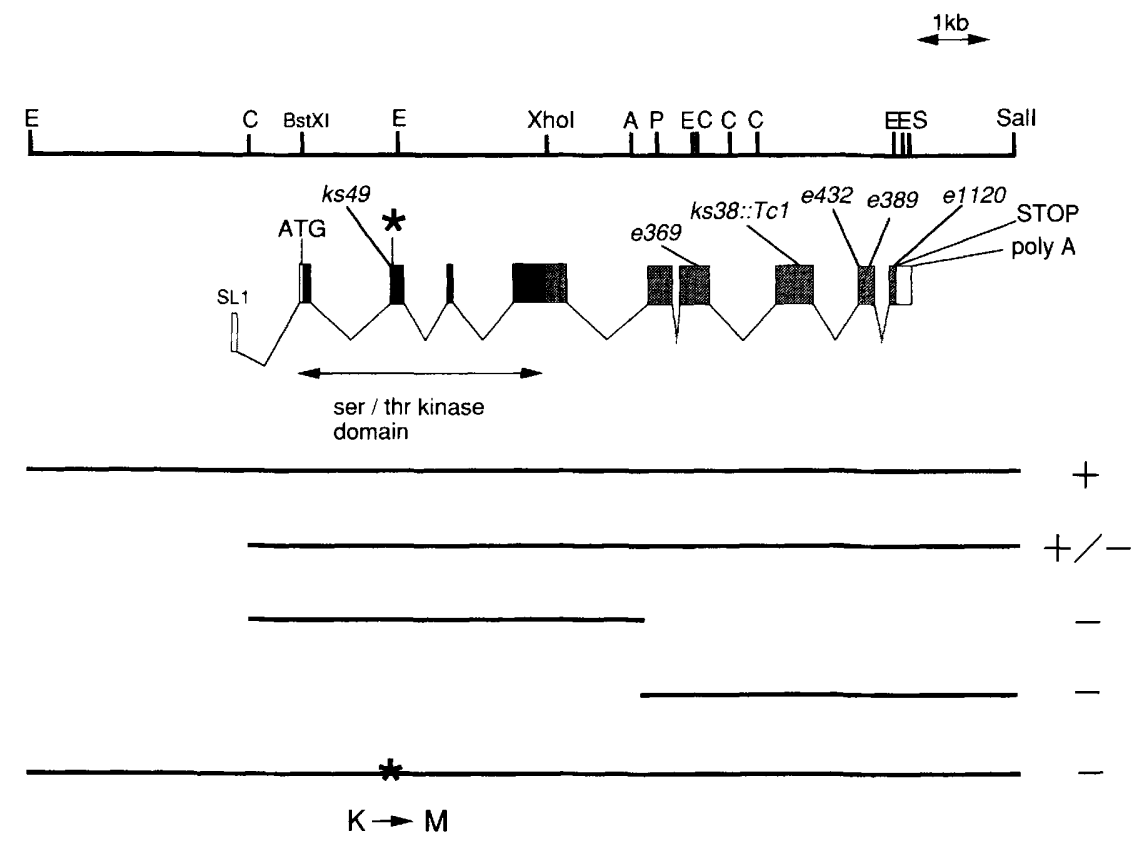




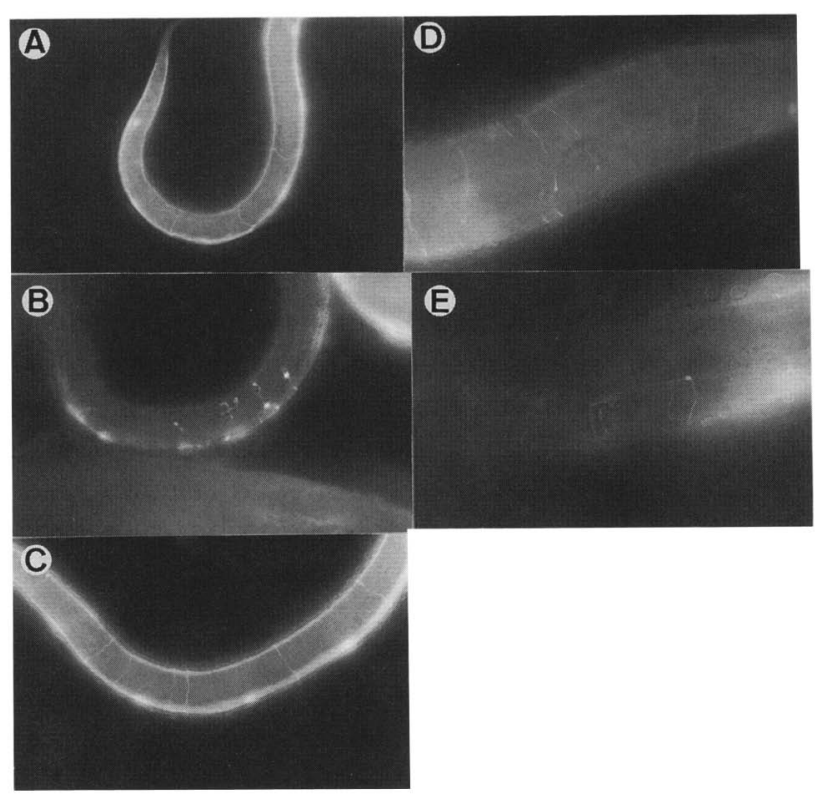

Figure 2. Indirect immunofluorescence staining of GABA-ergic neurons $(\mathrm{DD} / \mathrm{VD})$ with antisera to GABA. $|A|$ Wild-type animals; $(B)$ unc-51(e369) mutant; $(C)$ the unc-51(e369) rescued with the 13-kb EcoRI-Sall fragment of the wild-type unc-51 gene shown in Fig. 1 ; $(D)$ the dpy-20(e2017) mutant. $(E)$ dpy20(e2017) mutant that was transformed by coinjection of the unc-51 $(\mathrm{K} \rightarrow \mathrm{M})$ mutant gene and wild-type $d p y-20$ gene. The top of the panel represents the dorsal side of the animal.

periments, we conclude that the 13-kb EcoRI-Sall fragment contains the functional unc-51 gene.

\section{Analysis of unc-51 cDNA and mRNA}

Roughly $1.5 \times 10^{5}$ plaques of a $\lambda$ phage cDNA library, which was made from a $C$. elegans mixed-stage population of the wild-type N2, were screened with the Tc1flanking fragment, and 10 positive clones were detected. The longest (BLO) had an insert of $\sim 2.9 \mathrm{~kb}$, excluding poly(A). This cDNA and most of the corresponding genomic regions were sequenced, which revealed that the unc-51 gene includes nine exons (Figs. 1 and 3). To determine the 5 ' end of unc-51 cDNA, we carried out PCR analysis in which we used a primer of the SL1 and SL2 splice-leader sequences found in C. elegans mRNAs (Huang and Hirsh 1989) and an antisense primer to the 5' end of BLO. We found that the SL1 existed 24 bp upstream of the 5' end of BLO (Figs. 1 and 3). The nucleotide sequence of the cDNA contained a single open reading frame that encodes a putative 856 -amino-acid polypeptide, starting at the most $5^{\prime}$ methionine codon of the open reading frame (Figs. 1 and 3). The AUG start codon is preceded by an in-frame terminator codon; thus, the entire protein coding sequence is covered. A poly(A) tail is present at the end of a 302-nucleotides long 3'untranslated region, and a canonical polyadenylation signal (AATAAA) is located 17 bp upstream of the poly(A). These results indicate that the unc-51 gene encodes a protein of 856 amino acids.

\section{Putative Unc-51 protein has a serine/threonine} kinase catalytic domain near the amino terminus

The predicted amino acid sequence of the Unc-51 protein comprises at least two distinct domains (Figs. 1 and 3 ). An amino-terminal part of the sequence (amino acids 14-275) shows a significant homology to eukaryotic protein kinases (Hanks et al. 1988). Most of the amino acid identities found between the conceptual unc- 51 translational product and protein kinases reside in highly conserved residues that are appropriately spaced in the 12 recognized subdomains of the catalytic domain (Hanks et al. 1988) (Fig. 4). The sequence motifs DLKPQN in subdomain VIb (residues 134-139) and GSPMYM in subdomain VIII (residues 180-185) of Unc-51 indicate serine/threonine kinase substrate specificity (Hanks and Quinn 1991; Figs. 3 and 4).

By use of a data base that includes the sequences of $\sim 500$ kinases, the homology of the amino acid sequence of the predicted Unc-51 kinase domain was examined by K. Kuma (Kyoto University, Japan). Highest homologies were found with SNF1-related protein kinase of Arabidopsis thaliana $(38.1 \%$, Le Guen et al. 1992) and with human p $78 \mid 37.2 \%$, unpublished and found in GenBank 72 data base) (Fig. 4). Five other kinases in the data base showed an identity of $>32 \%$, including products of the Saccharomyces cerevisiae SNF1 gene (Celenza and Carlson 1986), the $S$. cerevisiae spk1 gene (Stern et al. 1991), and the Schizosaccharomyces pombe nim1 gene (Feilotter et al. 1991) (Fig. 4) and those of two other SNF1related genes (data not shown). However, when a phylogenetic tree of these kinases and related kinases, including KIN I and KIN II of S. cerevisiae (Levin et al. 1987), rabbit skeletal myosin light chain kinase (Herring et al. 1990), and mouse calcium-calmodulin-dependent protein kinase IV (Jones et al. 1991), was constructed, Unc51 was found to be only distantly related to any of the other kinases analyzed (K. Kuma, pers. comm.). The relatively long carboxy-terminal portion (residues 276-856) of the putative Unc-51 protein is distinct from all the other kinases so far identified and does not share significant sequence homologies with any of the proteins contained in the Swiss-Prot 28 (1994) data base. A hydropathy plot shows that the Unc-51 product contains no apparent hydrophobic membrane-spanning domain similar to those found in a variety of integral membrane proteins (Kyte and Doolittle 1982). Thus, Unc-51 seems to represent a novel kinase subfamily. It is similar to serine/ threonine kinases SNF1, p78, KIN I, KIN II, and PoLo (Llamazares et al. 1991), in that they have a relatively long carboxy-terminal portion.

\section{Mutation sites in the unc-51 mutants}

To determine functionally important regions of the unc51 gene, we localized mutation sites in six of the unc-51 mutants (Figs. 1,3; Table 1). In the ks38::Tc1 allele, a Tc1 was inserted within a protein-coding region downstream of the kinase domain. In the $e 369$ mutant, two point mutations were found: a silent mutation in the -1 opal 
A

ggtttaattacccaagtttgagaacctacctacaaaaccccccgccaaaacctatatagt SL1

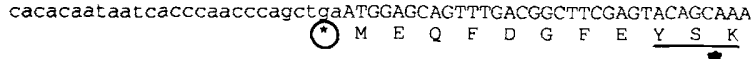
CGGGACCTTTTAGGTCATGGAGCATTTGCAATTGTATACAGAGGACGCTATGITGATCGC

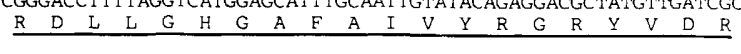
ACAGACGTGCCAGTTGCCATCAAGGCATCGCCAAGAAGAATATCAGCAAATCAAAGAAT

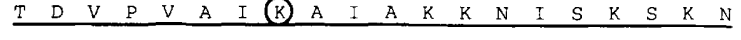
CTGCTGACAAAAGAGATTAAAATTCTAAAAGAATTGTCAAGCCTGAAGCATGAAAATCTT? \begin{tabular}{llllllllllllllllllll}
$L$ & $L$ & $T$ & $K$ & $E$ & $I$ & $K$ & $I$ & $L$ & $K$ & $E$ & $L$ & $S$ & $S$ & $L$ & $K$ & $H$ & $E$ & $N$ & $L$ \\
\hline
\end{tabular} GTGGGCCTACTCAAATGCACGGAGACCCCTACTCATGTGTATTTGGTTATGGAATTCTGT \begin{tabular}{llllllllllllllllllll}
$\mathrm{V}$ & $G$ & $\mathrm{~L}$ & $\mathrm{~L}$ & $\mathrm{~K}$ & $\mathrm{C}$ & $\mathrm{T}$ & $\mathrm{E}$ & $\mathrm{T}$ & $\mathrm{P}$ & $\mathrm{T}$ & $\mathrm{H}$ & $\mathrm{V}$ & $\mathrm{Y}$ & $\mathrm{L}$ & $\mathrm{V}$ & $\mathrm{M}$ & $\mathrm{E}$ & $\mathrm{F}$ & $\mathrm{C}$ \\
\hline
\end{tabular} AATGGAGGAGATTTGGCTGATTATTTACAACAGAAGACTACATTGAATGAGGATACTATT

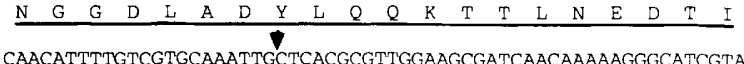

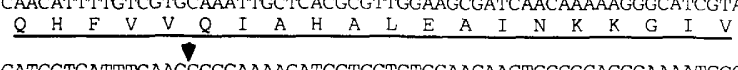

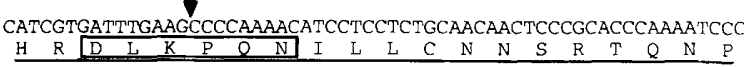
CACTTCACCGACATCGTCATCAAGCTTGCCGACTTTGGATTCGCCCGATTCC'TCAACGAC \begin{tabular}{llllllllllllllllllll}
$H$ & $F$ & $T$ & $D$ & $I$ & $V$ & $I$ & $K$ & $L$ & $A$ & $D$ & $E$ & $G$ & $F$ & $A$ & $R$ & $F$ & $L$ & N & D \\
\hline
\end{tabular} GGTGTGATGGCGGCAACTCTCTGCGGATCCCCAATGTACATGGCTCCCGAAGTCATAATG

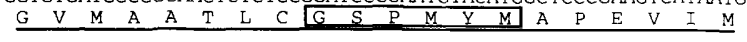
TCAATGCAATACGACGCGAAAGCCGATCTCTGGTCAATTGGAACCATCCTCTTCCAGTGT \begin{tabular}{lllllllllllllllllllllll}
$S$ & $M$ & $Q$ & $Y$ & $D$ & $A$ & $K$ & $A$ & $D$ & $L$ & $W$ & $S$ & $I$ & $G$ & $T$ & $I$ & $L$ & $F$ & $Q$ & $C$ \\
\hline
\end{tabular} CTCACCGGAAAAGCCCCATTCGTCGCGCAGACCCCGCCGCAGTTGAAGGCCTATTACGAG

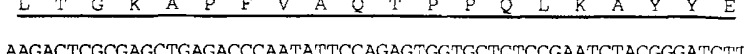

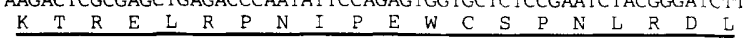
CTGTTGAGACTGCTCAAGAGAAACGCCAAGGATCGGATCTCGTTCGAAGACTTCTTCAAT \begin{tabular}{llllllllllllllllllll}
$L$ & $L$ & $R$ & $L$ & $L$ & $K$ & $R$ & $N$ & $A$ & $K$ & $D$ & $R$ & $I$ & $S$ & $F$ & $E$ & $D$ & $F$ & $F$ & $N$ \\
\hline
\end{tabular} CACCCGTTCCTCACCTCACCTCTCCTTCCGTCGCCGTCGAAGAGAATCCTCGAGAGCGCO

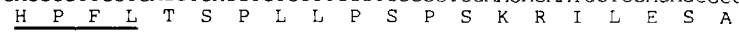

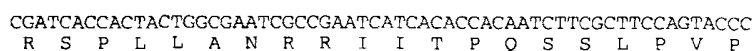

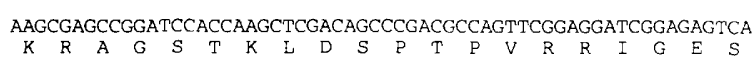

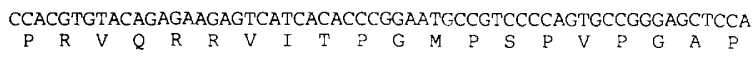

60

120

180

180
31

240

300

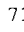

360
91

420

11

480
131

540

15

600

171

66

191

720
211

78

231

840

251

900

271

960
291

1020

311

1080

331

1140
351

Figure 3. Nucleotide sequence of the cDNA and the deduced amino acid sequence (single-letter code). Protein-coding sequences are shown in uppercase letters and untranslated sequences in lowercase letters. The SL1 splice-leader sequence is indicated by a broken line. The catalytic domain of the unc-51 protein kinase (Hanks et al. 1988) is underlined, and the presumed polyadenylation signal is indicated by double underlines. The stretches of amino acids suggesting serine/threonine substrate specificity (Hanks et al. 1988) are boxed. $(\nabla)$ The position of the Tc1 insertion in $k s 38:: T c 1$. The mutated codons in $k s E x$ 9, $e 369$, e389, and $e 1120$ mutations are circled (see also Table 1). The $5^{\prime}$ boundary of pBLO is shown by an arrow. The position of an intron is indicated by an arrowhead.

codon (TGA) to ochre (TAA), and an amber termination codon $\underline{T A G}$ in the $\underline{C A G}$ codon for Q553. The finding that $e 369$ has an amber (TAG) nonsense mutation is consistent with the previous result that this mutation was suppressed by tRNA ${ }^{\mathrm{Trp}}$ amber suppressors sup-5 and sup-7 (Kondo et al. 1990). In the $e 432$ and ks 49 mutants, the $3^{\prime}$ splice site $G\left(5^{\prime}-\mathrm{GT} \ldots \mathrm{A} \underline{\mathrm{G}}-3^{\prime}\right)$ of the seventh and first introns, respectively, was mutated to A $\left(5^{\prime}-\mathrm{GT}\right.$... AA-

B

ATGCAAGAGTCCACTGATTTCACTTTCCTTCCACCAAGGCAGGAATCCAGTCCGGTTAAG 1200

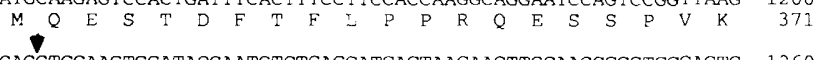

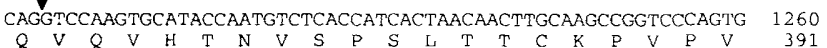
CCGAGTCAACGTTTGACCTACCAGAAAATGGAGGAGCGTCTGGCGGCTGCAAGAAAGACT 1320

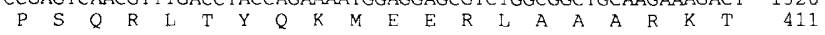
GCAGTGCCTTCTTCTTCTTCTCCAACAGGATCAGCGGTTTCTGCTCAGCATCAGCATCAG 1380

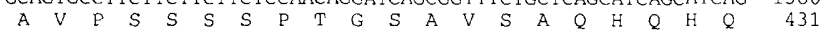
CATCAGCAGCAGCAGGAGCCCGCGTCGTCGCCGGTGGTTCAGCGGATTGAAAGGCCCGAT 1440

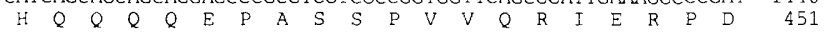
CAGCTGCCAAGACGGACTACGCTTCAGGATCCGATGCTCATGACATMGAGAGGATGACT 1500 $\begin{array}{lllllllllllllllllllll}Q & \mathrm{~L} & \mathrm{P} & \mathrm{R} & \mathrm{R} & \mathrm{T} & \mathrm{T} & \mathrm{L} & \mathrm{Q} & \mathrm{D} & \mathrm{P} & \mathrm{N} & \mathrm{A} & \mathrm{H} & \mathrm{D} & \mathrm{I} & \mathrm{E} & \mathrm{R} & \mathrm{M} & \mathrm{T} & 471\end{array}$ ATGCCGAATCCGACCTTCGTCGTATGTGGCAGCAGCACAAAACCATCGCCGAACAACGCG 1560 $\begin{array}{lllllllllllllllllllll}M & P & N & P & T & F & V & V & C & G & S & S & T & K & P & S & P & N & N & A & 491\end{array}$ AATCGCGTTCGCCGCTCCACCATCACAAGCCCCGCCGACACCCAGGATATGGTCGCTGCT 1620 $\begin{array}{lllllllllllllllllllll}N & R & V & R & R & S & T & I & T & S & P & A & D & T & Q & D & M & V & A & A & 511\end{array}$ GACCAAATGCTTTCGAACCTAGACCCCACCACCACCACCACCACCATCCCCAAATCGGCC 1680 $\begin{array}{lllllllllllllllllllll}D & Q & M & L & S & N & L & D & P & \mp & T & T & T & T & T & I & P & K & S & A & 531\end{array}$ ACCACAGCCAACATCCAGGGAATTCCACGTGGCGCTCGCGATCGATCGGTCACTTCGCCG 1740

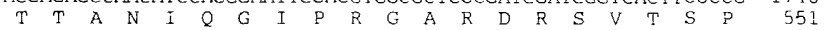
CCGCAGCCGACGATTCATGAGAATGAGCCGTGGATAATGCAAAGTATCAGCAGACGGAT 1800

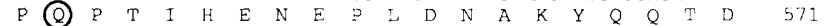

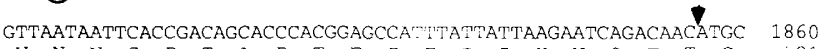
$\begin{array}{lllllllllllllllllllll}V & N & N & S & P & T & A & P & T & E & P & F & \text { I } & \text { I } & K & N & Q & T & T & C & b 91\end{array}$ TCCACATCCTCAACCTCCTCCTCAGTCGMCGAAGAGGAAGAGGCGATGAGTCTTCCA:TC 1920 $\begin{array}{lllllllllllllllllllll}S & T & S & S & T & S & S & S & V & V & E & E & E & E & A & M & S & D & D & 611\end{array}$ GCGTCTGGAAGCCATCTCGCAGCAGGATCAAGAAGACCCCCGCCGAGGMTCCAATGGAT 1980 $\begin{array}{llllllllllllllllllll}A & S & G & S & H & L & A & A & G & E & K & K & T & P & A & E & V & ? & M & D\end{array}$ CACGGAGCCCTACCACCAGCTTMGATCAGGAAATTGTGCTCGGCGAGGAGCACAAGCAG 2040 $\begin{array}{llllllllllllllllllll}H & G & A & L & P & P & A & L & D & Q & E & I & V & L & G & E & E & H & K & Q\end{array}$ ATTCTCGCGAAGCTTCGATTTGTCGCCAGCTCGTCGAIACCCTTATCCACGTGGCCGAG 2100

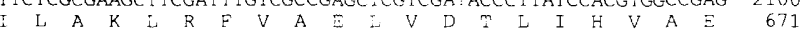
CAGAAGGACAATCCGTGGCGTCGGCGATGGCMACAAGAGACAGCTTTTGACTACTGGA 2160 $\begin{array}{lllllllllllllllllllll}Q & K & D & N & P & L & A & S & A & M & A & S & R & R & Q & L & L & T & T & G & 691\end{array}$ $\underset{\nabla}{\nabla}$ ACCTCAACGACTAATACATCGTCACCGRACCGGAGACCCGAGCAGCTGGTGGTGTACGTC 2220 $\begin{array}{llllllllllllllllllllll}T & S & T & T & N & T & S & S & P & Y & R & R & A & E & Q & L & V & V & Y & V & 71\end{array}$

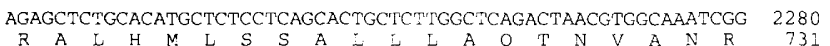
GTACTTCATCCGAGTGTCGCCGTGCAGCAGGTCTCAATCAGCTCAACGACAAGTATCAT 2340

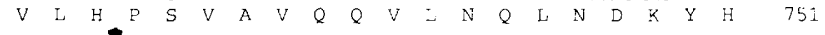
CAGTGTTTGGTCCGCTCCCAGGAGCTTGCC:CGCTTGGCCTCCCGGACAGGATCCGGCG 2400 $\begin{array}{lllllllllllllllllllll}Q & C & L & V & R & S & Q & E & L & A & S & L & G & \text { L } & \text { P } & G & Q & D & P & A & 77 ?\end{array}$ ATGGCGGTTATCTCGGCGGAAAGAA:CA CMACAGACATGCGATAGAACTGTGCCAGGCT 2460

C GCTGCTCTTGACGAGCTTTTTGGAAACCCCAGCTGTGCAGTCAGAGGTACCAGACCGCC 2520 $\begin{array}{lllllllllllllllllllll}A & A & L & D & E & L & F & G & N & \text { (P) } & Q & L & C & S & Q & R & Y & Q & T & A & 811\end{array}$ TACATGATGCTTCACACCTTGGCCGAGCAGGTCAATTGCGATCAGGATAAGACGGTGCTC 2580 $\begin{array}{llllllllllllllllllllll}Y & M & M & \text { L } & \text { H } & \text { T } & \text { L } & \text { A } & \text { E } & \text { Q } & \text { V } & \text { N } & C & \text { D } & Q & \text { D } & \text { K } & \text { T } & \text { V } & \text { L } & 831\end{array}$ ACGAGGTACAAAGTCGCTGTGGAAAAACGTCTTCGAATTCTGGAACGACAGGGATTTGTG 2640 $\begin{array}{llllllllllllllllllllll}T & R & Y & K & V & A & V & E & K & B & L & R & I & L & E & R & Q & G & F & V & 851\end{array}$ GCAGCTGTGAACACAtaatagtcettttaccccactettgttctgtttetgtgctget 2700 A A V N T * * 856

tcttcccccatttctacccegccaaaatgagcctctcccttgcaatgaacgtgtagccec 2760 ccactctattgaaaaatgagattttcactaccctaaacttct tagaattctttttctat 2820 tgttttaatgagatttttttttgaaaagacctgtaaatcccgttccggaactagtcgaa 2880 cataatgcatcattcgtgaataaattt 05 tgtacaaadaaaaaaaaaaaaaaaaaaa 2940 aaaaaaaaaaaaaaaaa

$\left.3^{\prime}\right)$. Abnormal transcripts, which used a cryptic $3^{\prime}$ splice site (Aroian et al. 1993), were present in these mutants (Fig. 5A,B). In the $e 389$ mutant, a recombination or a complex rearrangement was found, resulting in frameshift and premature termination (Fig. 5C). In the $e 1120$ mutant, a single $\mathrm{G} \rightarrow \mathrm{A}$ mutation was found near the carboxyl terminus of the putative coding region, changing the codon R841 (CGGT) into H (CATT). We sequenced 


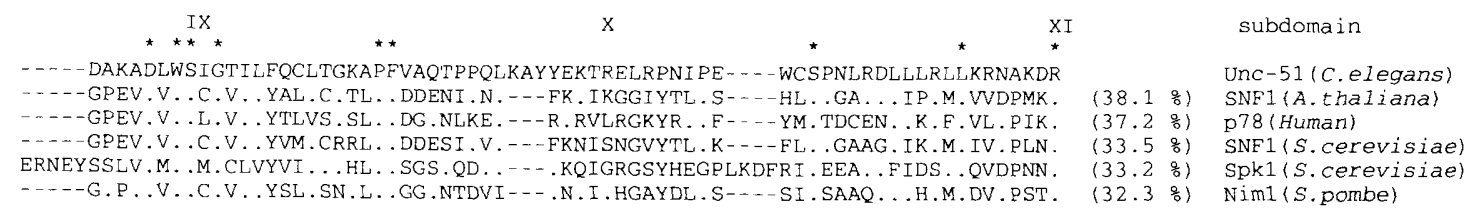

Figure 4. Amino acid sequence comparison of the kinase domains of the Unc-51 product with those of other serine/threonine kinases. The amino acid sequence of the putative serine/threonine kinase catalytic domain of Unc-51 was aligned with SNF1-related protein kinase of Arabidopsis thaliana (Le Guen et al. 1992), p78 of human (unpublished and found in GenBank 72), SNF1 of $S$. cerevisiae (Celenza and Carlson 1986), Spk1 of $S$. cerevisiae (Stern et al. 1991) and Nim1 of $S$. pombe (Feilotter et al. 1991). Residues shared by all kinases are marked with asterisks $\left({ }^{*}\right)$; dots signify amino acids identical to Unc-51; dashes indicate space for alignment. The stretches of amino acids suggesting serine/threonine specificity of the Unc-51 protein kinase are underlined. The position of the amino acid at the beginning of the catalytic domain is indicated on the first line of each sequence. The percentage of amino acid identity is indicated in parenthesis.

the coding region of the $e 1189$ mutant, but no mutation site was found. The reduced unc-51 mRNA level in this mutant (Fig. 6) suggests a mutation in a regulatory element outside of the coding region, which is important for transcription or mRNA stability.

Northern blot analysis for the unc-51 alleles

To analyze the mRNA of the wild-type and mutant unc-
51 alleles, Northern blot analysis was done with the unc51 cDNA probe (Fig. 6). In the wild type, a $3.1-\mathrm{kb}$ single band was seen (lane 1). In the ks38::Tc1, three bands were present (lane 3). We interpret the upper band to be an unc-51 transcript containing Tc1 sequence, and the middle band to be an intact or almost intact mRNA that arose from somatic excision of Tc1 DNA (Moerman et al. 1988). The lower band presumably arose by trunca-

Table 1. The phenotypes of unc-51 mutants and their mutation sites

\begin{tabular}{|c|c|c|c|c|}
\hline Strains & Movement & Egg laying & Body shape & Mutation site (codon) \\
\hline $\mathrm{N} 2$ & active & normal & normal & \\
\hline FK118(e432) & paralyzed & defective & dumpy (dpy) & $\begin{array}{l}3^{\prime} \text { splice site in intron } 7,(\mathrm{GT} \ldots \mathrm{AG}) \rightarrow \\
(\mathrm{GT} \ldots \mathrm{AA})\end{array}$ \\
\hline FK119(e369) & paralyzed & defective & dpy & $\begin{array}{l}-1 \text { opal }(\mathrm{TGA}) \rightarrow \text { ochre }(\mathrm{TAA}) \\
553 \mathrm{G} \ln (\mathrm{CAT}) \rightarrow \text { amber }(\mathrm{TAG})\end{array}$ \\
\hline FK120(e389) & paralyzed & defective & dpy & $\begin{array}{l}801 \operatorname{Pro}(\overline{\mathrm{C} C C}) \rightarrow \operatorname{Thr}(\mathrm{CT} \overline{\mathrm{C}}) \\
809 \mathrm{Gln}(\overline{\mathrm{CA} G}) \sim 823 \mathrm{Asn}(\underline{\mathrm{AAT}}), \text { deletions in } \\
\quad 35 \mathrm{bp}\end{array}$ \\
\hline FK121 $(e 1189)$ & paralyzed & defective & dpy & no mutation found in the coding region \\
\hline FK122(e1120) & paralyzed & defective & dpy & $841 \operatorname{Arg}(\mathrm{CGT}) \rightarrow \mathrm{His}(\mathrm{CAT})$ \\
\hline FK123(ks49) & $\begin{array}{l}\text { somewhat } \\
\text { active }\end{array}$ & defective & $\begin{array}{l}\text { somewhat } \\
\text { dpy }\end{array}$ & $\begin{array}{l}3^{\prime} \text { splice site in intron } \overline{\mathrm{I}},(\mathrm{GT} \ldots \mathrm{AG}) \rightarrow \\
(\mathrm{GT} \ldots \mathrm{AA})\end{array}$ \\
\hline FK51 $(k s 38:: T c 1)$ & fairly active & normal & $\begin{array}{l}\text { somewhat } \\
\text { dpy }\end{array}$ & $\begin{array}{l}\text { Tc1 insertion between } 696 \mathrm{Asn}(\mathrm{AAT}) \text { and } \\
697 \mathrm{Thr}(\mathrm{ACA})\end{array}$ \\
\hline FK124(ksEx9) & variable & variable & variable & 39 Lys $($ AAG) $\rightarrow$ Met (ATG) (created in vitro) \\
\hline
\end{tabular}

The unc-51 mutant strains of CB432(e432), CB369(e369), CB389(e389), CB1189(e1189), and CB1120(e1120) were backcrossed three times with N2. The resultant strains were named FK118(e432), FK119(e369), FK120(e389), FK121(e1189), and FK122(e1120). A mutant originally isolated by EMS treatment in this work was also backcrossed three times with N2, and FK123(ks49) was obtained. FK124(ksEx) strain was obtained by introduction of an unc-51 gene carrying a dominant negative mutation (Lys-39 $\rightarrow$ Met) into a dpy-20 mutant together with dpy-20 gene. 


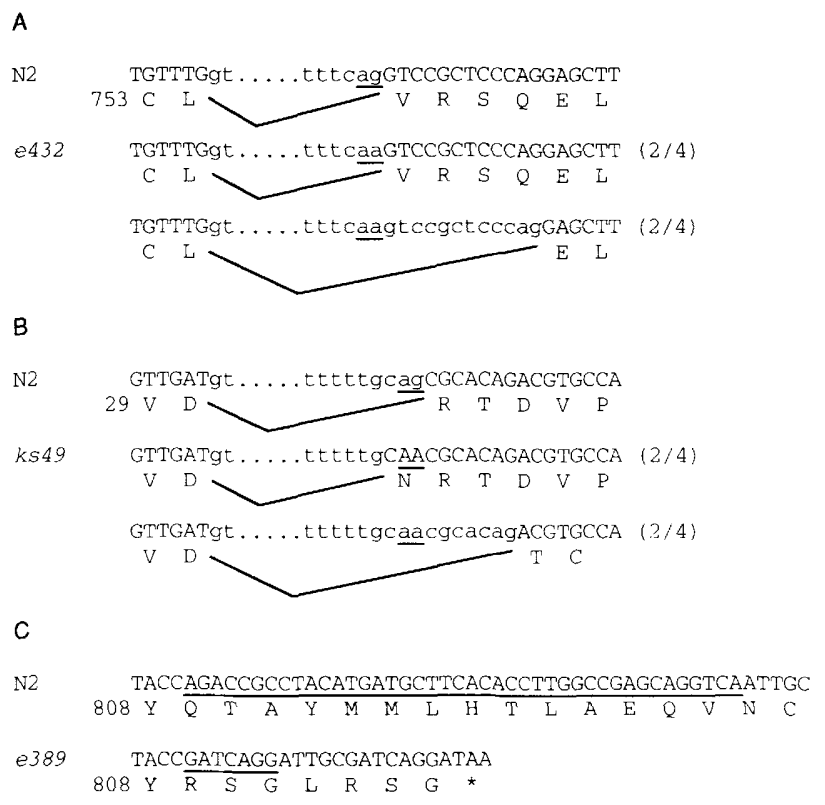

Figure 5. Mutations in the $e 432, k s 49$, and $e 389$ mutants. $(A)$ In the CB432(e432) mutant, two PCR-amplified cDNA clones show the same sequence as N2 (Aroian et al. 1993) in this region, but the other two clones show a 12-bp deletion, probably generated by use of a cryptic $3^{\prime}$ splice site as shown. (B) In the FK123(ks49) mutant, two PCR-amplified cDNA clones show 3-bp insertion but the other two clones show 7-bp deletions. These also arose by use of a cryptic $3^{\prime}$ splice site as shown. (C) In the cDNA of the CB389(e389) mutant, a complex mutation(s) was found in the underlined region of $42-\mathrm{bp}$, resulting in the frameshift.

tion or initiation in the Tc1 region. On the basis of the mRNA amounts relative to those of EF- $1 \alpha$ mRNA, unc51 mRNA levels in $e 369, e 389$, and $e 1120$ animals were not reduced much as compared with the wild type (lanes $2,4,6$; see also the legend Fig. 6). It seems that these mutations did not affect the unc-51 mRNA expression or stability. In $e 432, k s 49$, and $e 1189$ worms on the other hand, the relative mRNA levels were significantly reduced (lanes $5,7,8$ ).

\section{Expression of an unc-51/lacZ fusion gene}

To analyze expression pattern of the unc-51 gene, an unc-51/lacZ transcriptional fusion gene was constructed. The promoter region of the unc-51 gene (the 4-kb EcoRI-BstXI fragment; see Fig. 1) was inserted into the pPD21.28 plasmid that carries the SV40 nuclear localization signal (Fire et al. 1990). This fusion construct was introduced into the germ line of the unc-51(e369) mutant together with the intact unc-51 gene (the $13-\mathrm{kb}$ EcoRI-Sall fragment in Fig. 1). Wild-type transformant lines were isolated and examined by staining with X-gal. In the stages from the first larval (L1) through the adult stage (Fig. 7A-E), the lacZ fusion gene was expressed strongly in many or most neurons including those in the nerve ring near the head, those in the ventral nerve cords, and those near the tail. The IacZ fusion was also expressed in some non-neuronal cells, probably in body wall muscle nuclei (Fig. 7C,E) and pharyngeal muscle nuclei (Fig. 7E) (Okkema et al. 1993). The expression pattern was similar in these stages. Extensive and rather uniform staining was observed in the embryos (Fig. 7F).

As an approach to study the intracellular localization of the Unc-51 protein, an unc-51/lacZ translational fusion gene without a nuclear localization signal was constructed by insertion of the $l a c Z$ gene into the $13-\mathrm{kb}$ EcoRI-SalI fragment at the XhoI site shown in Figure 1 (after E289 in the amino acid sequence). The expression pattern of this construct was similar to that of the previous promoter fusion with a nuclear localization signal, except that staining was observed in the ventral nerve cord as well as in cell bodies (Fig. 8).

\section{Dominant-negative effect of a mutation in the kinase domain}

A homology search of the putative Unc-51 protein suggested that Unc-51 has serine/threonine kinase activity.
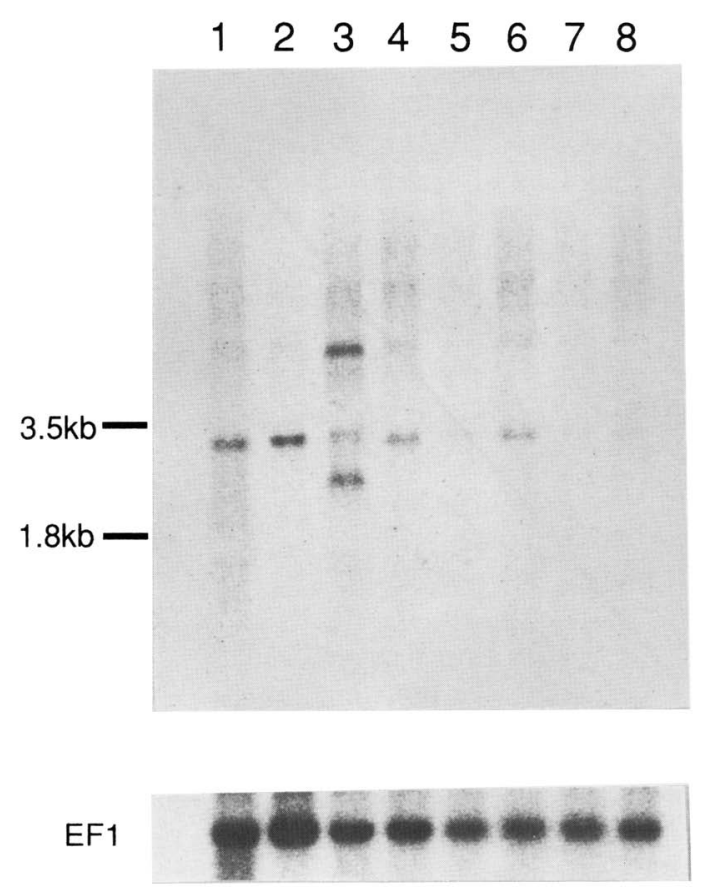

Figure 6. Northern blot analysis of poly $(A)^{+}$RNA of wild-type and unc-51 mutant worms. Poly $(\mathrm{A})^{+}$RNA $(5 \mu \mathrm{g})$ was resolved and blotted to nylon filter, and probed with unc-51 cDNA. (Lane 1) N2; (lane 2) e369; (lane 3) ks38::Tc1; (lane 4) e389; (lane 5) e432; (lane 6) e1120; (lane 7) ks49; (lane 8) e1189. The size of the RNA was estimated in reference to the $23 \mathrm{~S}$ and $18 \mathrm{~S}$ rRNAs. The same filter was rehybridized with the cDNA of $C$. elegans elongation factor $1 \alpha$ homolog (M. Koga, pers. comm.). unc-51 mRNA levels normalized by EF- $1 \alpha$ mRNA levels were $100 \%$ (N2), $67 \%$ (e369), $181 \%, 80 \%$, and $141 \%$ for top, middle, and bottom bands (ks38::Tc1), 76\% (e389), 36\% (e432), 96\% (e1120), $29 \%(k s 49)$, and $32 \%(e 1189)$. 


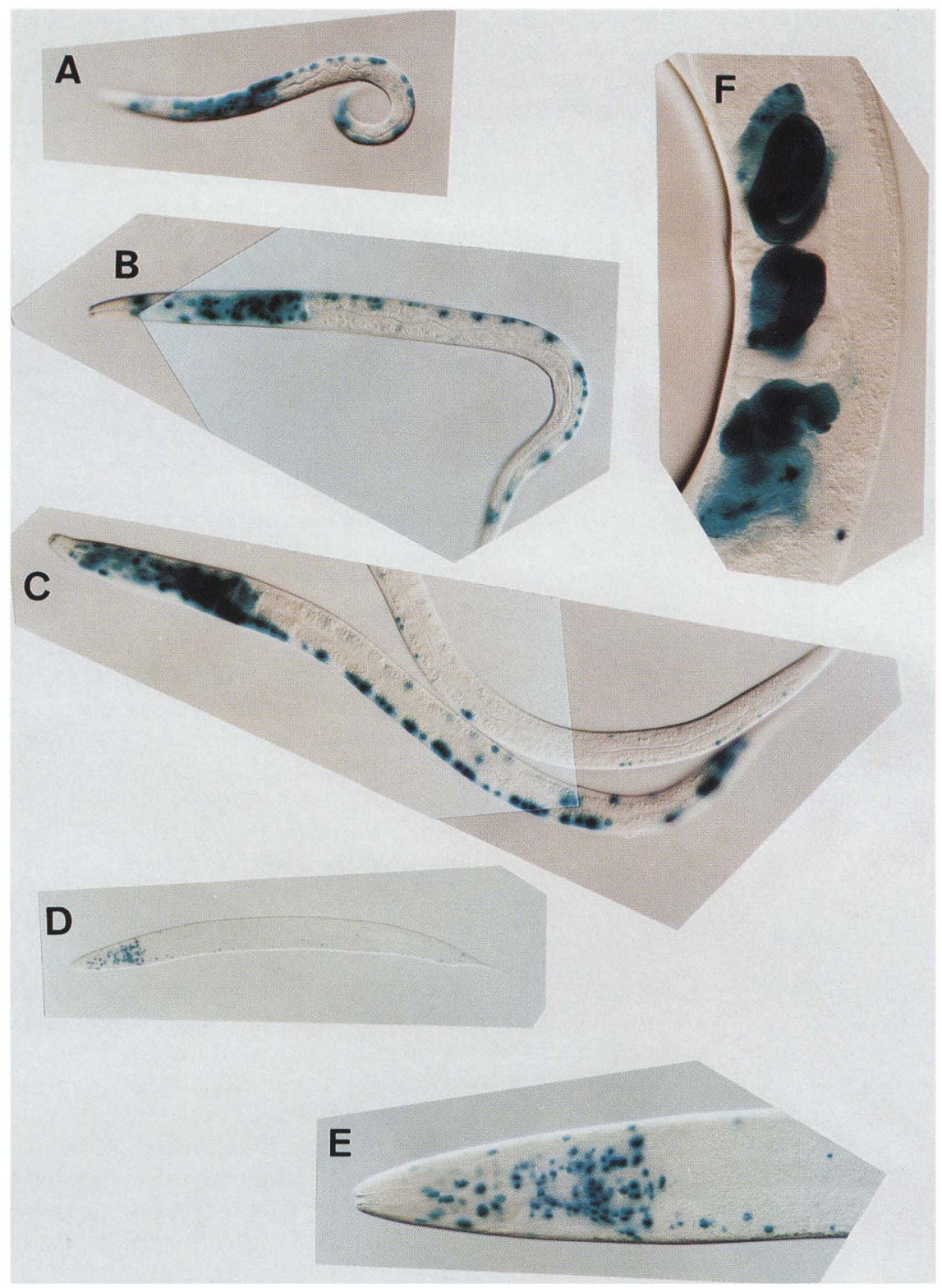

Figure 7. Expression pattern of an unc$51 /$ lac $Z$ promoter fusion gene with a nuclear localization signal. The unc-51(e369) mutant was transformed to non-Unc phenotype by germ-line introduction of the intact unc-51 gene and the plasmid pF4.0LZ Animals were fixed and stained with X-GAL. (A) L1 $(285 \times) ;(B)$ L2 $(285 \times) ;(C)$ L3 $(285 \times) ;(D)$ young adult $(71 \times) ;(E)$ head region of the young adult $(285 \times)$; and $(F)$ late embryos $(285 \times)$.
However, no mutation was found in the kinase domain. To analyze the importance of the kinase activity, the AAG codon of the genomic DNA corresponding to lysine (39) in the kinase domain was mutagenized to ATG for methionine in vitro. This lysine (39) is thought to be in an ATP-binding site of kinase domain (Han et al. 1993) and perfectly conserved in all protein kinases (Hanks et al. 1988); therefore, the mutagenized protein should not have any kinase activity. As expected, this mutagenized unc-51 gene did not rescue the mutant phenotypes of unc-51(e369) (Fig. 1).

To further confirm the importance of the Unc-51 kinase activity, a possible dominant-negative effect of the mutagenized unc-51 gene was analyzed as described by Han et al. (1993). In C. elegans, extrachromosomally transformed animals have several hundred copies of introduced genes, and the gene products are likely to be hyperproduced. If the kinase activity is essential for axonal elongation, inhibition of the functional Unc-51 kinase by a competition for the substrate or a possible regulatory factor with the hyperproduced Unc-51 mutant proteins should lead to the mutant phenotypes. The Lys (39) to Met unc-51 mutant gene (pF14M) was introduced into $d p y-20(e 2017)$ worms with the intact $d p y-20$ gene (pMH86) as a marker at the ratio of 9:1. Most of the transformed animals showed phenotypes characteristic to unc-51 mutants (Unc, Dpy, egg-laying defective, and axonal elongation defects) (Fig. 2E). Therefore, the kinase activity of the Unc-51 protein is probably essential for the function. The wild-type gene ( $\mathrm{pF} 14)$ was also intro- 


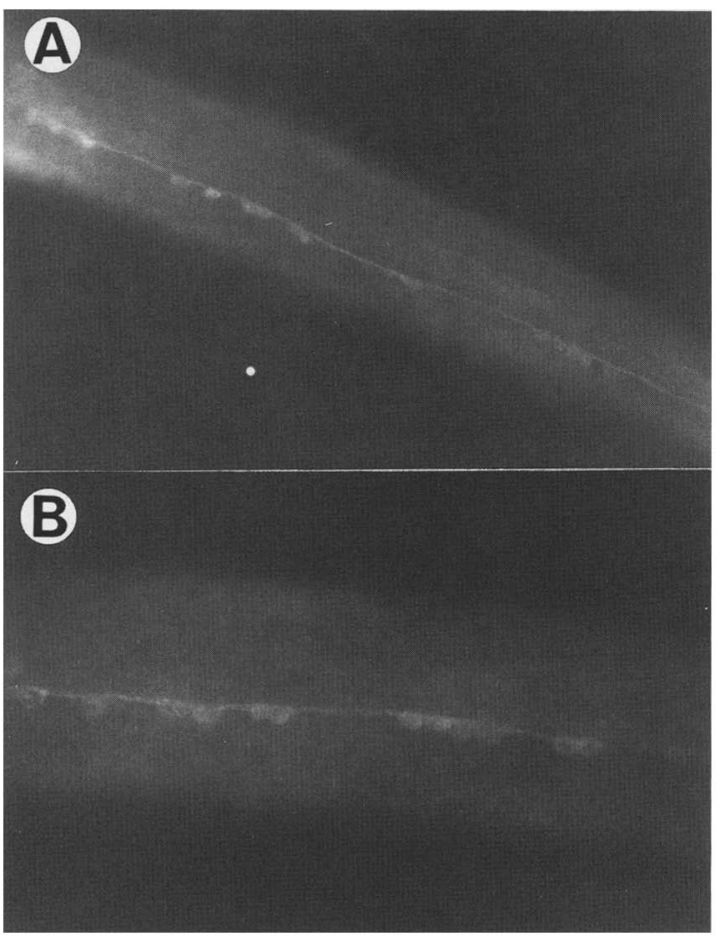

Figure 8. Expression of an unc-51/acZ translational fusion gene without a nuclear localization signal. The plasmid pF14LZ was introduced into the unc-51(e369) mutant together with the intact unc-51 gene. Non-Unc transformants were fixed and stained with the anti-LacZ antibody. (A) $552 \times ;(B) 875 \times$.

duced into $d p y$-21(e2017) worms with the intact $d p y-20$ gene, but no stable transformant lines were obtained. It is likely that overexpression of the wild-type gene is toxic, and therefore transformants are lethal.

\section{Discussion}

The unc-51 gene encodes a novel serine/threonine kinase

Sequence analysis of the unc-51 cDNA showed that the predicted Unc-51 protein is composed of at least two distinct domains, a serine/threonine kinase catalytic domain (Hanks et al. 1988) near the amino-terminal and a relatively long carboxy-terminal domain with an unknown function. In a phylogenetic analysis, the kinase domain could not easily be classified into any of the known serine/threonine kinase subfamilies (Hanks et al. 1988), and the unusually long carboxy-terminal portion did not share significant homologies with any of the proteins so far identified. It seems likely that the Unc-51 protein is a novel serine/threonone kinase.

\section{Analysis of unc-51 mutant alleles}

Mutant analysis showed that e369, ks38::Tc1, e432, $e 389$, and $e 1120$ had mutations in the carboxy-terminal portion and $e 1189$ had no mutation site in its coding region (Figs. 1,3; Table 1). Therefore, their Unc-51 products may have kinase activities if they are produced. Three mutants $e 432, k s 49$, and $e 1189$, showed significantly decreased unc-51 mRNA levels (Fig. 6). Both e432 and $k s 49$ mutants have a mutation at the $3^{\prime}$ splice site of an intron; hence such mutations decrease the efficiency of pre-mRNA splicing. FK51(ks38::Tc1) mutant is fairly active as compared with other mutants, and it is not egg-laying defective. Northern blot analysis showed evidence of intact unc-51 mRNA in addition to abnormal mRNAs (Fig. 6, lane 3). In this mutant, the Tc1 may be excised somatically (Moerman et al. 1988) or a part of the Tc1 sequence may be spliced out during mRNA formation, and some active Unc- 51 proteins are probably synthesized.

The mutation in the kinase domain created in vitro revealed that the kinase domain of Unc-51 is essential for the in vivo function. Such a mutation in the kinase domain is probably null. It is remarkable that all the mutation sites found in the unc-51-coding sequences of the isolated mutants were downstream of the kinase domain. In e369, e389, and e1120 mutants, their unc-51 mRNA levels were not reduced as much as the wild type (Fig. 6). These results suggest that the carboxy-terminal portion is also important for the function of Unc-51 protein. Mutations $e 369$, e389, and $e 1120$ may possibly be null based on their phenotypes. Alternatively, null mutations might be lethal. Mutations $k s 49$ and $k s 38:: T c 1$ are apparently reduced function mutations.

\section{Expression of the unc-51 gene}

During embryonic development when many neurons are extending their axons, the unc-51/lacZ fusion gene shows extensive expression, particularly in the head region of late embryos (Fig. 7F). In the larval stages, expression of the $l a c Z$ fusion appears to be restricted to neurons (Fig. 7A-C). Therefore, Unc-5l protein is likely to be necessary in neurons rather than in the cells along which their axons run. Furthermore, many neurons clearly expressed the unc-51/lacZ fusion gene in adult worms in which the axonal network had been constructed (Fig. 7D,E). This finding suggests that the Unc51 protein is required not only for axonal elongation but also either for the maintenance of axons by, for example, participating in membrane turnover (see the next section), or for an unknown neuronal function. Because most neurons expressed this fusion gene, we speculate that unc-51 mutants have axonal defects in the unexamined neurons as well as in DD, VD, PDE, and HSN neurons.

The function of Unc-51 protein in the formation of normal axonal structures

Expression pattern of the unc-51/lacZ fusion gene and observations of axonal defects in unc-51 mutants suggest that Unc-51 protein is required for axonal formation or elongation of most neurons. In support of this view, McIntire et al. (1992) found electron microscopic abnor- 
malities of axons such as enlargement of the diameter, atypical membranous vesicles, and cisternae-like structures in the axons of unc-51 mutants. They proposed that the outgrowth defects in unc-51 mutants could perhaps be a consequence of abnormalities in the structural components of axons, rather than in the components directly involved in guiding axonal elongation. Atypical membranous vesicles and cisternae-like structures are also found within presynaptic terminals in the temperature-sensitive shibire mutant of Drosophila (Koenig et al. 1983; Kosaka and Ikeda 1983). Blockage of neurite development and growth cone formation was found in neuronal cultures from the shibire mutant at the restrictive temperature, and these defects were presumed to be related to defective membrane recycling and endocytosis (Kim and Wu 1987). The shibire gene encodes a protein related to rat dynamin (van der Bliek and Meyerowitz 1991; Chen et al. 1991), a mechanochemical enzyme that interacts with microtubules (Obar et al. 1990; Vallee and Bloom 1991). Recently, it was reported that dynamin is identical to the neuronal phosphoprotein dephosphin (p96) and that on excitation, dynamin is phosphorylated and is quantitatively dephosphorylated in the nerve terminal (Robinson et al. 1993). Because the Unc51 protein is localized in axons and neural cell bodies (Fig. 8), it is tempting to speculate that the Unc-51 protein is involved in the membrane recycling of the axons by phosphorylation of a $C$. elegans dynamin homolog or another component in the pathway that includes a dynamin homolog.

Another possibility is that the Unc-51 protein phosphorylates and regulates a component that is not related to dynamin function but is required for the formation or function of the neuronal axons. Among such components in mammals, several proteins are known to be phosphorylated, such as GAP-43 (Skene 1989), calpactin I and II, synaptophysin, and synapsins (Trimble et al. 1991). Among these, at least synapsins are phosphorylated at serine residues. In C. elegans, unc-14, unc-33, and unc-44 mutants have axonal abnormalities similar to those in unc-51 mutants (Hedgecock et al. 1985; McIntire et al. 1992). Therefore, the function of the unc51 gene might be related to the functions of the genes specified by these mutants, or to the functions of C. $e$ egans homologs of the phosphorylated components in mammals.

\section{Possible functions of Unc-51 protein in axonal guidance or fasciculation}

In unc-51 mutants, axonal guidance and fasciculation seem to be abnormal in addition to various abnormalities in axonal structures. This apparent defect in axonal guidance and fasciculation may be solely due to a defect in the structure or function of the axonal membrane. Alternatively, it is possible that Unc-51 regulates the function or synthesis of a component(s) more directly involved in guidance or fasciculation, in addition to its function in the axonal structures. For example, in unc-51 mutants, the DD and VD axons terminate during cir- cumferential elongation to the dorsal nerve cord, and are abnormally defasciculated in the ventral nerve cord (Siddiqui 1990; McIntire et al. 1992; Fig. 2). The dorsal elongational defects of DD and VD axons were also observed in unc-5 and unc-6 mutants of C. elegans (Hedgecock et al. 1990; Siddiqui 1990; McIntire et al. 1992). The two genes encode a putative adhesion molecule (Leung-Hagesteijn et al. 1992) and a novel laminin-related molecule (Ishii et al. 1992), respectively. Hedgecock et al. (1990) proposed that the Unc- 6 proteins build up a circumferential gradient along the epidermal surface of $C$. elegans, and that the Unc-5 proteins function as the receptor at dorsal migrations (Hamelin et al. 1993). If this is the case, it is possible that in the DD/VD neurons, Unc-51 protein functions by the phosphorylation of a molecule in the pathway that transmits the Unc- 6 gradient signal through the Unc-5 receptor. The defasciculations of the DD and VD axons of the ventral nerve cord found in the unc-51 mutant may occur as a result of the inactivation or loss of some adhesion molecules like fasciclins of Drosophila (Grenningloh et al. 1991; Elkins et al. 1990). The expression of unc-51/lacZ translational fusion product in the ventral nerve cord (Fig. 8) supports this idea. The Unc-51 protein kinase might regulate such activities by phosphorylation.

\section{Materials and methods}

\section{C. elegans strains}

The unc-51 mutant strains $\mathrm{CB} 369(e 369)$ and $\mathrm{CB} 1189(e 1189)$ were provided by the Caenorhabditis Genetics Center (USA). $\mathrm{CB} 389(e 389), \mathrm{CB} 1120(e 1120)$ and $\mathrm{CB} 432(e 432)$ were provided by the Laboratory of Molecular Biology, Medical Research Council (MRC) (UK). Worms were grown on NGM agar plates at $20^{\circ} \mathrm{C}$ fed with the OP50 strain of Escherichia coli (Wood 1988).

\section{Cloning and structural analysis of the unc-51 gene}

Molecular manipulations were performed essentially according to Sambrook et al. (1989).

Molecular cloning of the 4.3-kb fragment in the unc-51 gene was performed as follows. The total DNA of FK51 was digested with EcoRI, and size-fractionated by electrophoresis in a $0.8 \%$ agarose gel. The 4- to $5-\mathrm{kb}$ fragments were purified and ligated to pUC19 vector. The resultant $C$. elegans partial genomic library was screened with the Tc1 DNA probe. From each of the positive clones, Tc1 was excised with EcoRV and the flanking sequence was used as a probe for Southern hybridization for the RFLP analysis. Hybridization was performed in $6 \times$ SSC, $5 \times$ Denhardt's solution, $0.5 \%$ SDS, $100 \mu \mathrm{g} / \mathrm{ml}$ of salmon sperm DNA, and $50 \%$ formamide at $42^{\circ} \mathrm{C}$ for $20 \mathrm{hr}$. The DNA probe was labeled with random priming of the DNA clone. Final washing was in $2 \times \mathrm{SSC}, 0.1 \% \mathrm{SDS}$, at $37^{\circ} \mathrm{C}$. Autoradiography was done at $-70^{\circ} \mathrm{C}$ for $40 \mathrm{hr}$ with an intensifying screen.

The wild-type unc-51 cDNA clone pBLO was isolated from a $\lambda$ Zap library (Barstead and Waterston 1989). Bluescript SK(-1 plasmids carrying the cDNA were excised in vivo following the protocol of Stratagene. The cDNA sequences were obtained by sequencing sets of nested exonuclease III deletions (Henikoff 1984 ) as well as various subcloned fragments in M13 or pUC18. Sequencing was carried out with the dideoxy chain termination method in both directions by use of Sequenase (U.S. Biochem- 
ical). The $5^{\prime}$ end of the wild-type unc-51 mRNA was determined by PCR analysis with the SL1 splice-leader sequence primer (5'-GGTTTAATTACCCAAGTTTGAG-3') and an antisense primer (5'-AAGCCGTCAAACTGCTCCAT-3') near the $5^{\prime}$ end of $\mathrm{pBLO}$.

The mutation sites were located by sequencing reverse transcription-PCR products (Sambrook et al. 1989) of the mutant poly $\{\mathrm{A}\}^{+}$RNA, except for ks38::Tc1 in which the Tc1 flanking region was sequenced. In e432, PCR-amplified genomic DNA containing the 7 th intron was sequenced, because abnormal splicing was observed.

\section{Transformation of C. elegans}

Following the method of Mello et al. (1991), DNA carrying a genomic fragment was injected into the syncytial gonads of unc$51(e 369)$ adult hermaphrodites at a total concentration of 100 $\mathrm{ng} / \mu \mathrm{l}$. The plasmid pTRU-1, which contains an unc-22 antisense RNA expression gene derived from pPD10.46 (Fire et al. 1991) and rol-6(su1006) gene (Kramer et al. 1990) derived from pRF4 was co-injected at 1:1 DNA ratio as a selection marker, and worms with the unc-22 mutant phenotype (twitcher) were selected. For cosmid F43A2 or pF14 carrying the 13-kb EcoRISall fragment, rescue of the unc-51(e369) phenotype was confirmed by microinjection of the DNA without another selection marker, but with 10-fold excess of a vector plasmid Bluescript $\mathrm{SK}|+|$ for dilution, because injection of cosmid F43A2 alone could not rescue the mutant phenotypes and therefore high copy numbers of this cosmid may be toxic. In this case, animals with the wild-type (non-Unc) morphology were selected as transformants.

\section{RNA procedures}

Total RNA from a mixed population of wild type (strain N2) and unc-51 mutant worms was prepared by the guanidine isothiocyanate method and poly(A) RNA was enriched on an oligo(dT) cellulose column (Sambrook et al. 1989). Five micrograms of the poly(A) RNA of the worms was resolved on a $1 \%$ formaldehydeagarose gel and blotted onto a nylon membrane filter (Biodyne A). Hybridization was performed in $6 \times$ SSC, $5 \times$ Denhardt's solution, $0.5 \%$ SDS, $100 \mu \mathrm{g} / \mathrm{ml}$ of salmon sperm DNA, and $50 \%$ formamide at $42^{\circ} \mathrm{C}$ for $20 \mathrm{hr}$. The probe was labeled with random priming of the $0.9-\mathrm{kb} E$ coRI fragment of the unc-51 cDNA clone. Final washing was done in $2 \times \mathrm{SSC}, 0.1 \%$ SDS, at $20^{\circ} \mathrm{C}$. Autoradiography was done with an imaging plate for $24 \mathrm{hr}$, which was analyzed with Fuji image analyzer BAS2000 (Fuji film). The filter was used for rehybridization with the C. elegans EF-1 $\alpha$ probe (M. Koga, pers. comm.).

\section{Indirect immunofluorescence for GABA antibody and $L a c Z$ antibody}

Staining with anti-GABA antibody was performed essentially according to the protocol described by McIntire et al. (1992) and Link et al. (1992). Staining with LacZ antibody was performed essentially according to the protocol described by Finney and Ruvkun (1990) except for the protocol of fixation ( $2 \%$ paraformaldehyde and $1 \times$ MRWB for $45 \mathrm{~min}$ at $4^{\circ} \mathrm{C}$.). LacZ antibody was obtained from Cappel. The specimens were observed by fluorescence microscopy (ZEISS Axioplan).

\section{Construction and expression of lacZ fusion constructs}

The putative promoter region of the unc-51 gene / the 4-kb EcoRI-BstXI fragment) was subcloned into the SmaI site of the
lacZ expression vector pPD21.28 (Fire et al. 1990). This plasmid was named $\mathrm{pF} 4.0 \mathrm{LZ}$. A mixture of pBluescript $\mathrm{SK} \mid+$ ) (for dilution), $\mathrm{pF} 14$, and $\mathrm{pF} 4.0 \mathrm{LZ}$ at the ratio of 10:1:1 was used for the transformation of the unc-51(e369) mutant. Fixation and staining was performed by the protocol described by Fire et al. (1990). The lacZ gene was subcloned in frame into the pF14 plasmid at the Xhol site. This plasmid was named $\mathrm{pF} 14 \mathrm{LZ}$. A mixture of pBluescript SK( + ) (for dilution), $\mathrm{pF} 14$, and $\mathrm{pF} 14 \mathrm{LZ}$ at the ratio of 10:1:1 was used for transformation of unc-51(e369) mutants. Animals of a non-Unc transformant line was used for staining with LacZ antibody.

\section{Preparation and analysis of a mutation in the kinase domain}

In vitro mutagenesis was done essentially according to the Kunkel method (Sambrook et al 1989). The 1-kb HindIII-EcoRI genomic DNA fragment including the Lys codon at position 39 and the 17-mer antisense mutagenized oligonucleotide $(K \rightarrow M)$ 5'-CGATCGCCATGATGGCA-3' were used for mutagenesis. This mutagenized fragment was used for reconstruction of the entire 13-kb DNA fragment corresponding to the unc-51 gene. The pF14M plasmid DNA bearing the mutagenized unc-51 gene was injected into $d p y-20$ worms together with pMH86 plasmid that contains the intact $d p y-20$ gene as a marker. The concentration of each plasmid used for injection was $90 \mathrm{ng} / \mu \mathrm{l}$ with $\mathrm{pF} 14 \mathrm{M}$ and $10 \mathrm{ng} / \mu \mathrm{l}$ with pMH86 in $10 \mathrm{~mm}$ Tris- $\mathrm{HCl}(\mathrm{pH} 7.5)$, $1 \mathrm{~mm}$ EDTA. Transformants were selected and analyzed for their axons by indirect immunofluorescence of GABA.

\section{Acknowledgments}

We thank A. Coulson and D. Albertson for the mapping of the cloned DNA, A. Coulson for a cosmid clone, R. Barstead and R. Waterston for the cDNA library, D. Baillie and P.W. Sternberg for pMH86, A. Fire for pPD21.28 and pPD10.46, J.M. Kramer for pRF4, the Caenorhabditis Genetics Center and J. Hodgkin for the gift of mutant worms, K. Kuma for the analysis of homology and phylogeny, $H$. Gachoud for excellent technical assistance, K. Saigo for the LacZ antibody, H.R. Horvitz, M. Koga, T. Tani, and other members of our laboratories for suggestions and discussions, and M. Ohara for comments. This research was funded by a grant from the Ministry of Education, Science and Culture, of Japan, a grant from the Science and Technology Agency of Japan, and by a Swiss National Science Foundation grant (31-31001.91).

The publication costs of this article were defrayed in part by payment of page charges. This article must therefore be hereby marked "advertisement" in accordance with 18 USC section 1734 solely to indicate this fact.

\section{References}

Aroian, R.V., A.D. Levy, M. Koga, Y. Ohshima, J.M. Kramer, and P.W. Sternberg. 1993. Splicing in Caenorhabditis elegans does not require an AG at the 3 ' splice acceptor site. Mol. Cell. Biol. 13: 626-637.

Bargmann, C.I. and H.R. Horvitz. 1991. Chemosensory neurons with overlapping functions direct chemotaxis to multiple chemicals in C. elegans. Neuron 7: 729-742.

Barstead, R.J. and R.H. Waterston. 1989. The basal component of the nematode dense-body is vinculin. J. Biol. Chem. 264: 10177-10185. (1989)

Brenner, S. 1974. The genetics of Caenorhabditis elegans. Ge netics 77: 71-94.

Celenza, J.L. and M. Carlson. 1986. A yeast gene that is essential 
for release from glucose repression encodes a protein kinase. Science 233: 1175-1180.

Chalfie, M. and J.G. White. 1988. The nervous system. In The nematode Caenorhabditis elegans (ed. W.B. Wood), pp. 337391. Cold Spring Harbor Laboratory, Cold Spring Harbor, New York.

Chen, M.S., R.A. Obar, C.C. Schroeder, T.W. Austin, C.A. Poodry, S.C. Wadsworth, and R.B. Vallee. 1991. Multiple forms of dynamin are encoded by shibire, a Drosophila gene involved in endocytosis. Nature 351: 583-586.

Coulson, A., J. Sulston, S. Brenner, and J. Karn. 1986. Toward a physical map of the genome of the nematode Caenorhabditis elegans. Proc. Natl. Acad. Sci. 83: 7821-7825.

Desai, C., G. Garriga, S.L. McIntire, and H.R. Horvitz. 1988. A genetic pathway for the development of the Caenorhabditis elegans HSN motor neurons. Nature 336: 638-646.

Dodd, I. and T.M. Jessell. 1988. Axon guidance and the patterning of neuronal projections in vertebrates. Science 242: 692699.

Elkins, T., K. Zinn, L. McAllister, F.M. Hoffmann, and C.S. Goodman. 1990. Genetic analysis of a Drosophila neural cell adhesion molecule: Interaction of fasciclin I and Abelson tyrosine kinase mutations. Cell 60: 565-575.

Feilotter, H., P. Nurse, and P.G. Young. 1991. Genetic and molecular analysis of $c d r 1 / n i m 1$ in Schizosaccharomyces pombe. Genetics 127: 309-318.

Finney, M. and G. Ruvkun. 1990. The unc-86 gene product couples cell lineage and cell identity in C. elegans. Cell 63: 895-905.

Fire, A., S.W. Harrison, and D. Dixon. 1990. A modular set of lacZ fusion vectors for studying gene expression in Caenorhabditis elegans. Gene 93: 189-198.

Fire, A., D. Albertson, S.W. Harrison, and D.G. Moerman. 1991. Production of antisense RNA leads to effective and specific inhibition of gene expression in C. elegans muscle. Development 113: 503-514.

Goodman, C.S. and C.J. Shatz. 1993. Developmental mechanisms that generate precise patterns of neuronal connectivity. Cell 72: Neuron 10: 77-98.(Suppl.)

Guen, L.L., M. Thomas, M. Bianchi, N. G. Halford, and M. Kreis. 1992. Structure and expression of a gene from Arabidopsis thaliana encoding a protein related to the SNF1 protein kinase. Gene 120: 249-254.

Grenningloh, G., E.J. Rehm, and C.S. Goodman. 1991. Genetic analysis of growth cone guidance in Drosophila: Fasciclin II functions as a neuronal recognition molecule. Cell 67: 4557.

Hall, D.H. and E.M. Hedgecock. 1991. Kinesin-related gene unc104 is required for axonal transport of synaptic vesicles in $C$. elegans. Cell 65: 837-847.

Hamelin, M., Y. Zhou, M.-W. Su, I.M. Scott, J.G. Culotti. 1993. Expression of the UNC-5 guidance receptor in the touch neurons of $C$. elegans steers their axons dorsally. Nature 364: 327-330.

Han, M., A. Golden, V. Han, and P.W. Stemberg. 1993. C. elegans lin-45 raf gene participates in let-60 ras-stimulated vulval differentiation. Nature 363: 133-140.

Hanks, S.K., and A.M. Quinn. 1991. Protein kinase catalytic domain sequence database: Identification of conserved features of primary structure and classification of family members. Methods Enzymol, 200: 38-62.

Hanks, S.K., A.M. Quinn, and T. Hunter. 1988. The protein kinase family: Conserved features and deduced phylogeny of the catalytic domains. Science 241: 42-52.

Harrelson, A.L. and C.S. Goodman. 1988. Growth cone guidance in insects: Fasciclin II is a member of the immunoglob- ulin superfamily. Science 242: 700-708.

Hedgecock, E.M., J.G. Culotti, J.N. Thomson, and L.A. Perkins. 1985. Axonal guidance mutants of Caenorhabditis elegans identified by filling sensory neurons with fluorescein dyes. Dev. Biol. 111: 158-170.

Hedgecock, E.M., I.G. Culotti, and D. H. Hall. 1990. The unc-5, unc- 6 , and unc- 40 genes guide circumferential migrations of pioneer axons and mesodermal cells on the epidermis in $C$. elegans. Neuron 2: 61-85.

Henikoff, S. 1984. Unidirectional digestion with exonuclease III creates targeted breakpoints for DNA sequencing. Gene 28: 351-359.

Herring, B.P., J.T. Stull, and P.J. Gallagher. 1990. Domain characterization of rabbit skeletal muscle myosin light chain kinase. I. Biol. Chem. 265: 1724-1730.

Huang, X.-Y. and D. Hirsh. 1989. A second trans-spliced RNA leader sequence in the nematode Caenorhabditis elegans. Proc. Natl. Acad. Sci. 86: 8640-8644.

Ishii, N., W.G. Wadsworth, B.D. Stern, J.G. Culotti, and E.M Hedgecock. 1992. UNC-6, a laminin-related protein, guides cell and pioneer axon migrations in $C$. elegans. Neuron 9: $873-881$.

Jones, D.A., J. Gold, D. Wilson-Shaw, W.E. Hahn, and J.M. Sikela. 1991. cDNA sequence and differential expression of the mouse $\mathrm{Ca}^{2+} /$ calmodulin-dependent protein kinase IV gene. FEBS Lett. 289: 105-109.

Kim, Y.-T. and C.-F. Wu. 1987. Reversible blockage of neurite development and growth cone formation in neuronal cultures of a temperature-sensitive mutant of Drosophila. I. Neurosci. 7: 3245-3255.

Koenig, J.H., K. Saito, and K. Ikeda. 1983. Reversible control of synaptic transmission in a single gene mutant of Drosophila melanogaster. J. Cell Biol. 96: 1517-1522.

Kondo, K., B. Makovec, R.H. Waterston, and J. Hodgkin. 1990. Genetic and molecular analysis of eight tRNA ${ }^{\text {Trp }}$ amber suppressors in Caenorhabditis elegans. J. Mol. Biol. 215: 7-19.

Kosaka, T. and K. Ikeda. 1983. Reversible blockage of membrane retrieval and endocytosis in the garland cell of the temperature-sensitive mutant of Drosophila melanogaster, shibi$r e^{\text {ts1 }}$. J. Cell Biol. 97: 499-507.

Kramer, J.M., R.P. French, E. Park, and J.J. Johnson 1990. The Caenorhabditis elegans rol-6 gene, which interacts with the sqt-1 collagen gene to determine organismal morphology, encodes a collagen. Mol. Cell. Biol. 10: 2081-2089.

Kyte, J. and R.F. Doolittle. 1982. A simple method for displaying the hydropathic character of a protein. J. Mol. Biol. 157: 105132.

Leung-Hagesteijn, C., A.M. Spence, B.D. Stern, Y. Zhou, M.-W Su, E.M. Hedgecock, and J.G. Culotti. 1992. UNC-5, a transmembrane protein with immunoglobulin and thrombospondin type 1 domain, guides cell and pioneer axon migrations in C. elegans. Cell 71: 289-299.

Levin, D.E., C.I. Hammond, R.O. Ralston, and J.M. Bishop. 1987. Two yeast genes that encode unusual protein kinases. Proc. Natl. Acad. Sci. 84: 6035-6039.

Li, W., R.K. Herman, and J.E. Shaw. 1992. Analysis of the Caenorhabditis elegans axonal guidance and outgrowth gene unc-33. Genetics 132: 675-689.

Link, C.D., M.A. Silverman, M. Breen, K.E. Watt, and S.A. Dames. 1992. Characterization of Caenorhabditis elegans lectin-binding mutants. Genetics 131: 867-881.

Llamazares, S., A. Moreira, A. Tavares, C. Girdham, B.A. Spruce, C. Gonzalez, R.E. Karess, D.M. Glover, and C.E. Sunkel. 1991. polo encodes a protein kinase homolog required for mitosis in Drosophila. Genes \& Dev. 5: 2153 2165. 
McIntire, S.L., G. Garriga, J. White, D. Jacobson, and H.R. Horvitz. 1992. Genes necessary for directed axonal elongation or fasciculation in C. elegans. Neuron 8: 307-322.

McIntire, S.L., E. Jorgensen, and H.R. Horvitz. 1993a. Genes required for GABA function in Caenorhabditis elegans. $\mathrm{Na}$ ture 364: 334-337.

McIntire, S.L., E. Jorgensen, J. Kaplan, and H.R. Horvitz. 1993b. The GABAerbic nervous system of Caenorhabditis elegans. Nature 364: 337-341.

Mello, C.C., J.M. Kramer, D. Stinchcomb, and V. Ambros. 1991. Efficient gene transfer in C. elegans: Extrachromosomal maintenance and integration of transforming sequences. EMBO I. 10: 3959-3970.

Moerman, D.G., G.M. Benian, R.J. Barstead, L. Schriefer, and R.H. Waterston. 1988. Identification and intracellular localization of the unc-22 gene product of Caenorhabditis ele. gans. Genes \& Dev. 2: 93-105.

Mori, I., D.G. Moerman, and R.H. Waterston. 1988. Analysis of a mutator activity necessary for germline transposition and excision of $\mathrm{Tcl}$ transposable element in Caenorhabditis elegans. Genetics 120: 397-407.

Obar, R.A., C.A. Collins, J.A. Hammarback, H.S. Shpetner, and R.B. Vallee. 1990. Molecular cloning of the microtubule-associated mechanochemical enzyme dynamin reveals homology with a new family of GTP-binding proteins. Nature 347: 256-261.

Perkins, L.A., E.M. Hedgecock, J.N. Thomson, and J.G. Culotti. 1986. Mutant sensory cilia in the nematode Caenorhabditis elegans. Dev. Biol. 117: 456-487.

Robinson, P.J., J.-M. Sontag, J.-P. Liu, E.M. Fykse, C. Slaughter, H. McMahon, T.C. Südhof. 1993. Dynamin GTPase regulated by protein kinase $\mathrm{C}$ phosphorylation in nerve terminals. Nature 365: 163-166.

Sambrook, J., E.F. Fritsch, and T. Maniatis. 1989. Molecular cloning: A laboratory manual. Cold Spring Harbor Laboratory Press, Cold Spring Harbor, New York.

Siddiqui, S.S. 1988. Mutations affecting growth and guidance of mechanosensory neurons in the nematode Caenorhabditis elegans. Soc. Neurosci. Abstr. 14: 596.

. 1989. Axonal outgrowth and process placement of sensory lumbar neurons in the nematode Caenorhabditis elegans. In Neurobiology of sensory systems led. R.N. Singh and N.J. Strausfeld), pp. 241-265. Plenum Publishing, New York.

- 1990. Mutations affecting axonal growth and guidance of motor neurons and mechanosensory neurons in the nematode Caenorhabditis elegans. Neurosci. Res. (Suppl.) 13: $171-190$.

Siddiqui, S.S. and J.G. Culotti. 1991. Examination of neurons in wild type and mutants of Caenorhabditis elegans using antibodies to horseradish peroxidase. I. Neurogenet. 7: 193211.

Skene, J.H.P. 1989. Axonal growth-associated proteins. Annu. Rev. Neurosci. 12: 127-156.

Stern, D.F., P. Zheng, D.R. Beidler, and C. Zerillo. 1991. Spk1, a new kinase from Saccharomyces cerevisiae, phosphorylates proteins on serine, threonine, and tyrosine. Mol. Cell. Biol. 11: $987-1001$.

Trimble, W.S., M. Linial, and R.H. Scheller. 1991. Cellular and molecular biology of the presynaptic nerve terminal. Annu. Rev. Neurosci. 14: 93-122.

Vallee, R.B. and G.S. Bloom. 1991. Mechanisms of fast and slow axonal transport. Annu. Rev. Neurosci. 14: 59-92.

van der Bliek, A.M. and E.M. Meyerowitz. 1991. Dynamin-like protein encoded by the Drosophila shibire gene associated with vesicular traffic. Nature 351: 411-414.
White, J.G., E. Southgate, J.N. Thomson, and S. Brenner. 1986. The structure of the nervous system of Caenorhabditis elegans. Philos. Trans. R. Soc. Lond. B 314: 1-340.

Wood, W.B. 1988. The Nematode Caenorhabditis elegans. Cold Spring Harbor Laboratory, Cold Spring Harbor, New York. 


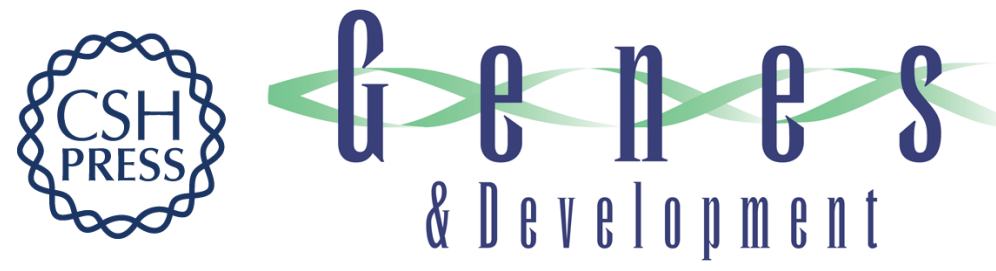

\section{Caenorhabditis elegans unc-51 gene required for axonal elongation encodes a novel serine/threonine kinase.}

K Ogura, C Wicky, L Magnenat, et al.

Genes Dev. 1994, 8:

Access the most recent version at doi:10.1101/gad.8.20.2389

References This article cites 59 articles, 23 of which can be accessed free at:

http://genesdev.cshlp.org/content/8/20/2389.full.html\#ref-list-1

License

Email Alerting

Service

Receive free email alerts when new articles cite this article - sign up in the box at the top right corner of the article or click here.

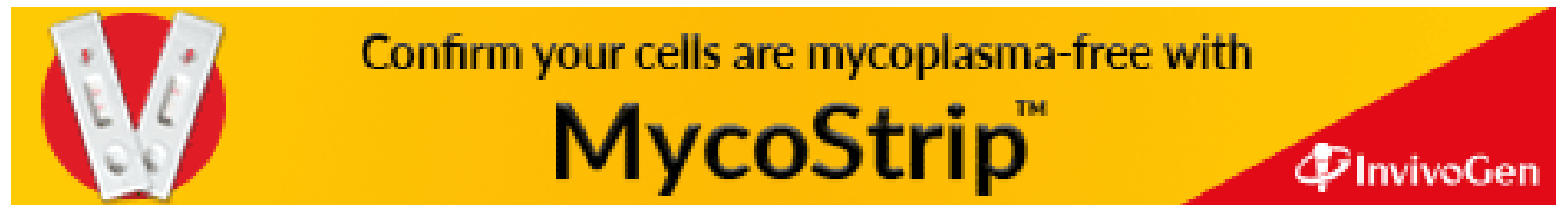

